\title{
An Examination of Needs Analysis Research in the Language Education Process
}

\author{
Hülya Sönmez* \\ Education Faculty, Muş AlparslanUniversity, Muş, Turkey
}

Corresponding author: Hülya Sönmez, E-mail: hulya.sonmez@alparslan.edu.tr

\begin{tabular}{l} 
ARTICLE INFO \\
\hline Article history \\
Received: November 27, 2018 \\
Accepted: January 20, 2019 \\
Published: January 31, 2019 \\
Volume: 7 Issue: 1 \\
\hline
\end{tabular}

Conflicts of interest: None

Funding: None

\begin{abstract}
The aim of this study is to analyze research methods, data collection tools, and data analysis methods of the needs assessment studies conducted in the language education and teaching process. In this study, the general screening model, which is based on an examination of research on needs analysis, was used. The data collected in accordance with the general screening model were examined by the content analysis method based on the examination of the documents. The methods of these studies, data collection tools, and data analysis methods were reviewed. In accordance with the results from the review process, the frequency of use, efficiency, and functionality of the research method, data collection tool and data analysis methods used were evaluated. Next, during the needs assessment process, the importance and priority of students' and teachers' needs were discussed. The results of these discussions have been included at the end of the research. In the light of the findings of the research and the results, suggestions were made regarding the importance of teacher and student needs factors in the process of identifying and analyzing language education needs. The classification made shows that researchers generally concentrate on four models which are mixed, survey, descriptive and experimental models. As for the data collection tools, it is understood that different data collection tools are used in the sample studies to determine the needs.
\end{abstract}

Key words: Needs Analysis, Language Education-instruction, Analysis, Language Education-instruction, Method

\section{INTRODUCTION}

The term "need" may refer to an obligation, demand, and necessity (Martins, 2017, p. 58). The term "needs analysis", which has become widespread in ESP (English for Specific Purposes) and EAP (English for Academic Purposes) courses, is also called "needs assessment". The purpose of the needs analysis is to identify the target language teaching/ learning needs in order to design an effective curriculum. In assessing the special needs of students, we encounter the term "need analysis", which had different connotations in the past than it does currently. The needs analysis was carried out in the early stages of ESP (1960s and early 1970s) to evaluate students' communication needs and the techniques of achieving specific teaching objectives. Nowadays, the tasks of needs analysis vary considerably since the needs analysis aims to gather information about students' needs (Otilia, 2015). Tarone and Yule (1989) reported four levels of needs analysis according to learners' learning needs, which are the global, rhetorical, grammatical-rhetorical and grammatical levels. Global needs analysis tries to determine which target conditions the target language will need in order to realize the learning process effectively. Thus, it determines the target needs of students in relation to the language. Rhetoric and grammatical-rhetorical needs analyses are related to each other as the grammatical-rhetorical needs analysis tries to determine which linguistic forms are used to realize the structure of knowledge at the rhetorical level. Grammatical needs analysis is related to the frequency in which grammatical forms are used in certain communicative situations (Çelik, 2003).

Needs analysis in the language education process develops within the scope of certain objectives depending on the purpose of the research. Objectives of the needs analysis in the educational process are as follows: information on the aims of students to follow a learning program on the basis of information gathered through various sources, analysis of the current situation in order to provide information on the effectiveness of the program, which is carried out according to the current and future needs of the students, information on preferred learning or learning styles, information on the preferences of learners for specific skills and preferences for learning these skills, factors determining the role relationship between teachers and students; and information related to preferences for teaching-learning activities (Dudley-Evans and John, 1998, p. 125).

A needs analysis to be conducted based on these purposes and an evaluation process resulting from such a needs analysis consist of different stages which are closely related to one another. The six key steps required to carry out a needs as- 
sessment are listed as follows: determining goals, determining the boundaries of the universe in which the needs analysis is to be conducted, determining the limits of the test case (test), choosing the data collection tool, collecting evidence, evaluating the data, and criticizing the study in terms of its effectiveness (Schutz and Derwing 1981, cited in Jeczelewski, 2016, p. 13). Duddley-Evans and John (2009) classify needs analysis into five groups according to the functions of needs analysis: objective situation analysis and objective needs analysis covering the tasks and activities that learners will use to use English; linguistic analysis giving information about how language and skills are used, discourse analysis, genre analysis; analysis of instructional needs covering similar situations such as prior learning experiences, reasons for participating in the curriculum, expectations, etc. This means that subjective need factors that influence learning styles depend on the needs of the learners; appropriate case analysis to identify students' current skills and language use; meaning analysis to give information about how the lesson will be done or the environment to be studied.

Depending on the teaching process of ESP, Stern (1992) focuses on four kinds of ESP teaching objectives, which are proficiency, knowledge, affective and transfer goals. These objectives are described as follows: The provincial proficiency targets; four skills in reading, writing, listening and speaking. Knowledge objectives include the acquisition of linguistic and cultural information. Language knowledge consists of awareness of language analysis and systematic aspects. Affective targets are related to the development of positive emotions associated with the topic. Finally, transfer targets include the ability to make generalizations from a situation or at another time (cited in Otilia, 2015, p. 54-55). In the 1970s, the target situation analysis (TSA) focusing on "how much" and for "what". This approach dealt with determining requirements. Munby’s (1978) analysis focuses entirely on needs analysis when the needs analysis is strong (West, 1998, cited in Mohammadi and Mousavi, 2013). Munby set up a "Communicative Needs Processor" (CNP) analysis to determine curriculum achievements. This analysis includes a large number of different questions to determine the profile of learners' language needs. Although Munby's model has shown various improvements and progress in needs analysis, it has also been criticized for some aspects. These criticisms are focused on aspects such as analysis' being complex and time-consuming, excluding learners' perceptions, neglecting socio-political conditions, bearing logistical and administrative constraints and drawing skills from social English (Jordan, 1997; West, 1994 cited in Mohammadi and Mousavi, 2013). These criticisms of Munby's approach brought up the questions of "how" and "what" to the agenda in the needs analysis. Thus, the question of "what needs to be kept in mind?" became important in order to determine language needs and to learn a language. In addition to this, the question of "how" gained importance in the language learning process. These questions led to various pedagogic needs analysis approaches. These analyses complement TSA (Target Situation Analysis); deficiency analysis, strategy analysis and means analysis (Jordan, 1997; West, 1994, 1998 cited in Mohammadi and Mousavi,
2013). The present situation analysis (PSA) was developed by Richterich and Chancerel (1980, cited in Mohammadi and Mousavi, 2013). This analysis is related to the concepts "means needs" and "ends needs" and focuses on what learners like to learn when learning the target language. With regard to these concepts, "means needs" help students to learn their language needs while "ends needs" are related to the current situation (learning needs). The "deficiency analysis", which is a combination of TSA (Target Situation Analysis) and PSA (Present Situation Analysis), is an approach based on the analysis of the current state of the learners as well as the current situation (e.g. Allwright, 1982; Robinson, 1991, cited in Mohammadi and Mousavi, 2013).

After the 1980s, needs analysis studies seemed to change direction according to learning styles. As a result of this trend, the "language audit analysis" approach emerged. This analysis covers large-scale research in a company, an organization or a country (Jordan, 1997; West, 1994). Therefore, in this analysis, it is thought that students' individual language needs should be followed up with more advanced analyses. As a result, the needs analysis has become a matter of language planning, and language inspections involve largescale research in a company, an organization or a country (Jordan, 1997; West, 1994, cited in Mohammadi and Mousavi, 2013). Hutchinson and Waters (1987) addressed the needs in two main categories. These are called target needs (i.e. what the learner needs to do in the target situation) and learning needs (i.e. what the learner needs to do in order to learn). The target needs include the following content that the individual needs to learn about the language. For example, there are many ways to deal with the problem and wants to learn the language. These are closely related to concepts such as necessities, lacks, and wants. Dudley-Evans and John (1998) emphasized concepts such as present knowledge/required knowledge, objective/subjective needs, and perceived/felt needs. Hutchinson and Waters (1987) tried to identify the target situation analysis framework with the following questions: How will the language be used? What will the content areas be? With whom will the learner use the language? Where will the language be used? When will the language be used? Objective needs are related to the accumulation of knowledge about the learners' language learning skills. Linguistic difficulties and linguistic competencies that a learner experiences during the language learning process can be given as examples. Subjective needs point to learners' perceptions, attitudes, and expectations about language (Robinson, 1991; Brindley, 1989, cited in Martins, 2017). The main difference between objective/subjective and perceived/felt needs concerns the data collection processes of these needs. Moving from these differences Stufflebeam et al. (1985) described the four philosophies involved in the teaching of NAs in education: the philosophy of difference, it is the distance between students' language needs and their current linguistic competencies; democratic philosophy, these are the needs that are preferred by the majority of the stakeholders involved in the language education process; analytical philosophy, - when the learning characteristics and learning processes are taken into consideration, needs include the next stage; the philosophy of diagnosis, the rela- 
tionship between diet and drugs, needs are essential elements of language performance; consequently they may be harmful if not developed (cited in Mohammadi and Mousavi, 2013).

Researchers explain the characteristics of these seven stages of processes as follows: (a) must be based primarily on the philosophy of culture and organization; (b) must be proactive rather than reactive,; (c) use a method that has a distinctive feature that distinguishes learning needs from other needs not addressed by education; (d) directly or indirectly, interested in education and various organizational actors interested in participating in the teaching; (e) focus on the largely observable skills of leaders, managers, and professionals; (f) consider the various uses of sampling techniques and data analysis; and finally (g) to have a cost/benefit analysis at the end of the process (Wright and Geroy, 1992).

The following tools are often used to describe the needs of language teaching-learning: questionnaire, interview, observation, discussion, telephone interview, and their combinations. Among them, questionnaires are the most widely used tools. Especially, the needs analysis based on speaking was determined to be more effective. The features of a good speaking analysis are as follows: be easy to understand and fill in, be good for learners with little or no experience in assessing their own ability, be easy to use as a basis for an interview by an inexperienced interviewer, cover all important aspects, give all information needed to tailor a course, not require an interview (i.e. participants can do the needs analysis at home), be good for analyzing many people at the same time, be good for analyzing individuals, be easy to evaluate, be easy to compare different individual needs profiles (Kohoutova, 2006). In the following review, a detailed analysis of the use of these tools was carried out. In the light of the theoretical results presented by these studies, it is examined how this theoretical knowledge is used in sample studies. Thus, the theoretical framework of this study is to determine the use of these results in experimental research. In brief, the theoretical framework of this research focuses on how needs analysis is done in language education. These results are given in detail in the following sections.

\section{Purpose, Scope and Research Question}

The main purpose of this study is to identify methods, data collection tools, and data analysis methods used in the needs analysis in the needs assessment studies conducted in the language education and teaching process. In line with this purpose, the research consists of books, articles, and theses published or issued between 2002 and 2017. The 74 studies collected in this context were examined according to the determined criteria. The result of the examination showed that 17 of them were not suitable for the purpose of the research. With the omission of these 17 studies, 57 studies were examined. Based on the research process, an answer to the basic research question has been sought. According to the data collected from the sample studies, we focused on the following research question. "How are the methods, data collection tools and data analysis methods used in research on the language education-teaching process?"

\section{MATERIALS AND METHOD}

The data were collected from the following databases: YÖK Thesis Database; Marmara University, Boğaziçi University, and Muş Alparslan University Library Database and Google Academic Databases [Wiley Online Library, Web of Knowledge (ISI), Proquest, PsycNet (APA)]. In order to collect the data, the following keywords were written on the relevant search engines: "learning needs, teaching needs, teaching needs assessment, training, teaching needs analysis and learning, teaching needs analysis, teaching needs evaluation, corporate training, and university, development, and education". The studies were reviewed by the author and three domain experts in accordance with the criteria provided in Table 1 .

In the study, a general screening model based on the examination of the data taken from a sample or samples from a part of or the entire universe was used to reach general conclusions about the needs assessment studies conducted in the language education and teaching process (Karasar, 2013). At the same time, a content analysis based on the examination of documents related to a certain subject area was used in the research (Yıldırım and Şimşek, 2013). The methods, data collection tools and data analysis methods used in the sample studies were determined. The collected data according to the stages of the content analysis were analyzed according to the following steps: determining the keywords to search for, determination of categories, organization, and definition of data according to codes and categories, categorization and interpretation of findings reached.

\section{RESULTS}

The model of the needs analysis, data collection tools, and data analysis methods conducted in the field of language

Table 1. The criteria to review the sample studies

\begin{tabular}{|c|c|}
\hline Subject of study & Explanation \\
\hline Research purpose & The researchers' purposes in analyzing the needs are examined. \\
\hline Research model & Research models used in the needs analysis process were examined. \\
\hline Data collection tools & The data collection tools used to identify needs were examined in the research. \\
\hline Data analysis method & Data analysis methods used to analyze collected data in research were examined. \\
\hline The sample & The needs analysis was examined to determine groups' needs. \\
\hline $\begin{array}{l}\text { The words used in the research instead } \\
\text { of the concept of need }\end{array}$ & $\begin{array}{l}\text { The concepts used to identify and analyze needs were examined in the sample studies. These } \\
\text { concepts were compared to the concepts used in the literature in the process of needs analysis. }\end{array}$ \\
\hline
\end{tabular}


education are examined in this part of the research. In this context, the sample studies are examined in three categories and in terms of the relations of these categories with one another. The first category covers the research models that researchers use to determine needs during the language education process. In this context, the model of each researcher was determined and these are chronologically (Appendix A). Then, the models used in the sample research are divided into categories.

This classification shows that researchers generally concentrate on four models which are mixed, survey, descriptive and experimental models. The frequency of use of these models in the sample research is shown in Figure groups (Figure 1). Among them, research based on experimental models seems to be quite few. At the same time, the mixed method is the second model that has been preferred less by researchers. Apart from these, the findings indicate that to determine the needs of the language, the sample research more often uses survey and descriptive models. These include more specific case studies. This finding suggests that research concentrates on the identification of current needs situations. A similar situation can be seen in surveys based on screening models. In the research, the needs of the language education-teaching process were determined by screening. These results support previous research findings (Ferreira and Abbad, 2013, pp. 86-87).

Figure 2 shows that different data collection tools are used in the sample studies to determine the needs. The reason why the data collection tools differ stems from the combination of several different data collection tools in one study. The figure groups (Figure 2) shows that different data collection tools are used. The utilization rates of these different data collection tools are quite different from one another since most of the surveys were used during the data collection process. The reason for this is closely related to the research model used because the questionnaire was used mostly as data collection tools in descriptive and screening-based research (Ferreira and Abbad, 2013, pp. 86-87). It has been determined that these questionnaires used in the sample studies are mostly structured and semi-structured. Interview forms are the second most commonly used means in the sample research. Interview forms have been used in these studies because of the frequent use of interview techniques for gathering data, especially in the models based on screening. As a matter of fact, in the previous studies, it was determined that the questionnaire is the most commonly used tool in the needs analysis (Long, 2005, p. 39). On the other hand, observation forms, documents, scales, and tests were preferred less by researchers.

Another issue covered in this section is the analysis methods used to analyze data in the process of determining needs. When we look at data collection tools in Figure groups (Figure 3 ), it is seen that more than one analysis method is used in sample research. Researchers used SPSS, content, mix, frequency, and percentage, coding, and needs analysis to analyze their data. In terms of their frequency of use, it appears that the analysis based on the SPSS program constitutes a large majority. It has been determined that these analyses made in the SPSS program are mostly composed of descriptive analyzes. The reason for this is closely related to the research model and data collection tools used. At the same time, frequency and percentage analyses used in the second rank are also closely related to the model used. Therefore, in this section, we can make a general: It has been concluded that the research model, data collection tools and data analysis methods used in the research are compatible with each other. Therefore, the type and characteristics of the examinations made in all three charts (Figure groups) are

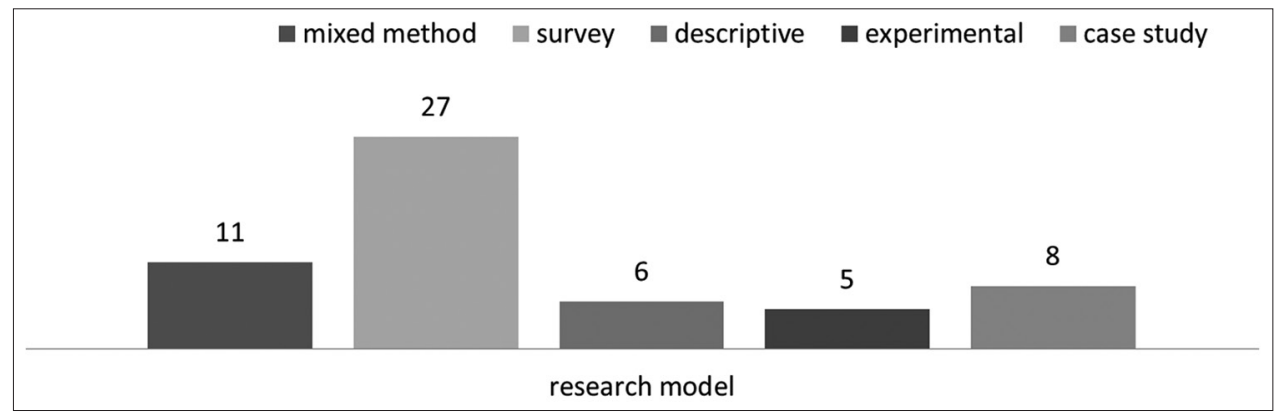

Figure 1. Research models

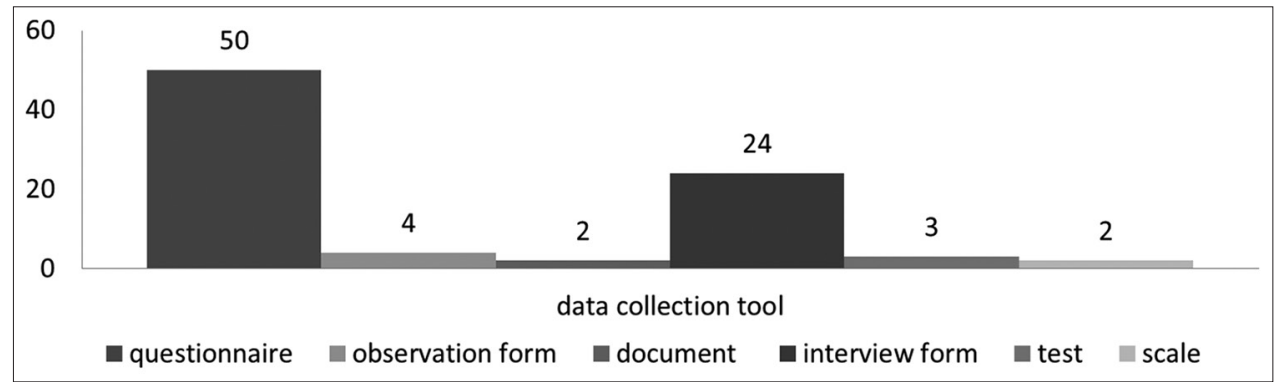

Figure 2. Data collecting tools 


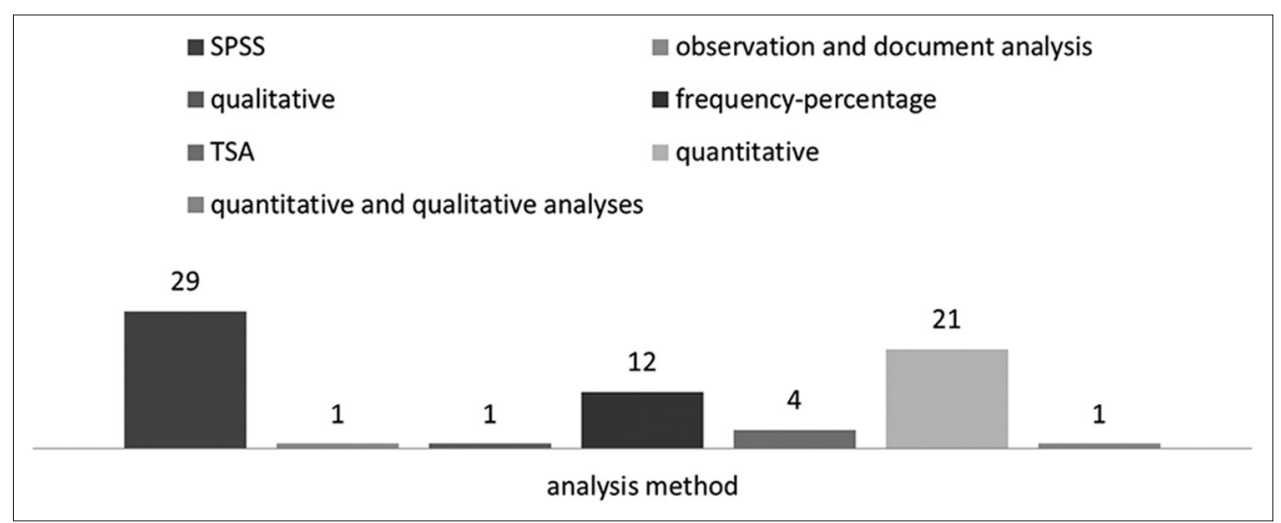

Figure 3. Data analysis methods

quite similar. However, their effectiveness, their adequacy, and functionality in the process of identifying and analyzing the needs of language education and teaching are also discussed in the discussion section.

When the results of this research are compared with Long's research, a different finding shows up (2005, pp. 31-32). This comparison shows that the data collection processes used in the process of determining the needs have varied over time. Long gives the data collection process of the research carried out between 1970-2002 as follows: "diaries, journals and logs; role-plays, simulations; content analysis; discourse analysis; analysis of discourse; register/ rhetorical analysis; computer-aided corpus analysis; genre analysis; task-based, criterion-referenced performance tests, triangulated; non-expert intuitions; expert practitioner intuitions; unstructured interviews; structured interviews; interview schedules; surveys and questionnaires; language audits; ethnographic methods; participant observation; nonparticipant observation; classroom observation ". As is seen, the data collection processes used in the years 1970-2002 are more different than they are in the sample studies. In other words, it can be suggested that the studies conducted between 1970-2002 involved more different processes than the studies conducted between 2002-2017. This suggests that the different methods used to collect the data in the language need analysis decreased over time since researchers mostly (between years 2002-2017) preferred to use survey and interview forms as data collection tools. At the same time, descriptive and screening coding and frequency analyses are the most frequently used analyzes. Appendix A provides more detailed information about this section.

\section{DISCUSSION AND CONCLUSION}

Chegeni and Chegeni (2013) listed the research processes of the needs analysis as "questionnaires, self-ratings, interviews, meetings, collecting learner language samples, task analysis, case studies and analysis of available information". It is difficult to deduce that this arrangement is adequate to determine the language needs. However, an examination of Figure groups indicates that some of these concepts are used in the sample studies. Survey and descriptive models are often used to identify needs in the sample studies. Although survey and descriptive models have been used extensively in these studies, it is difficult to say whether they are sufficient and effective in determining the needs entirely. In this context, it has been determined that the mixed method, which is very effective in determining both qualitative and quantitative needs, is not sufficiently used in sample studies. This factor needs to be taken into account in the needs assessment studies. Thus, future studies should focus on research models in which both qualitative and quantitative methods are used together since the purpose of the research varies qualitatively or quantitatively according to the topic or scope of the research. Due to this variety, there is a need for model or models of research in which different research methods are used together in order to conduct appropriate and effective research.

In the sample studies, data collection tools with different features and functions were used. Their frequency or rate of use shows that there is a large distribution of variance since the majority of the data collection tools are comprised of questionnaires. The reason for this is, of course, closely related to the research model. But the tools used to identify the needs are a very important element in the language education process because these needs are determined by the data collection tools used. As it has been emphasized earlier, the aims of the research are qualitative or quantitative, depending on the research topic or scope. As a result of this difference, the needs of language education should be examined both qualitatively and quantitatively. For this reason, qualitative and quantitative data collection tools should be used together to determine needs. On the other hand, it has been observed that quantitative data collection tools are used more often to identify needs in the sample studies.

The results of the study can be summarized as follows: The classification made shows that researchers generally concentrate on four models which are mixed, survey, descriptive and experimental models. The result of the classification indicates that to determine the needs of the language, the sample research uses survey and descriptive models more often. This finding suggests that research concentrates on the identification of current needs situations. This result shows that research on needs analysis only focuses on specific models. However, it is necessary to take advantage of different models for the needs analysis in language education.

A similar result is seen in the frequency of data collection tools. A look at data collection tools shows that surveys were 
mostly used during the data collection process. The reason for this is closely related to the research model used because the questionnaire was used mostly as data collection tools in the descriptive and screening-based research. Therefore, data collection tools should be enriched depending on the research models used in the needs analysis as this affects the analysis methods used for need analysis.

\section{REFERENCES}

Akçadağ, T. (2010). Öğretmenlerin ilköğretim programındaki yöntem teknik ölçme ve değerlendirme konularına ilişkin eğitim ihtiyaçları. Bilig, 53(Bahar, Sayı), 29-50.

Alebachew, S. (2016). Analysis of the English language needs of BSc nursing students: the case of higher education institutions in Bahir Dar City, Ethiopia. English for Specific Purposes World, 50 (17), 1-27.

Alfehaid, T. A. F. (2011). Developing an ESP curriculum for students of health sciences through needs analysis and course evaluation in Saudi Arabia (Doctoral Dissertation), University of Leicester, UK.

Al-Hamlan, S. A. (2013). EFL curriculum and needs analysis: an evaluative study. Kingdom of Saudi Arabia ministry of higher education King Saud University MA TESOL CI584 Syllabus Design.

Al-Hamlan, S. A. (2015). A needs analysis approach to EFL syllabus development for second grade students in secondary education in Saudi Arabia: a descriptive analytical approach to students' needs. American International Journal of Contemporary Research, 5(1), 118-145.

Angus, K. B. (2014). Meeting the needs of foreign language teaching assistants: professional development in American universities (PHD-A Dissertation). The University of Arizona.

Arık, S. (2002). An investigation into the requirements of discipline teachers for academic English language use in a Turkish medium university (MA Thesis). Bilkent University, Ankara.

Ayas, Ö., \& Kırkgöz, Y. (2013). The academic and vocational English language needs of the school of health students. Çukurova University Faculty of Education Journal, 42(1), 39-55.

Aydın, Y. (2014). Erasmus yoğun dil kurslarında Türkçe öğrenen yabancllara yönelik bir ihtiyaç analizi. Ondokuz Mayıs Üniversitesi Eğitim Bilimleri Enstitüsü, Türkçe Eğitimi Anabilim Dalı, Yüksek Lisans Tezi.

Baig, M. (2012). Needs analysis of second language learners with particular regard to their writing skills. IOSR Journal of Humanities and Social Science (JHSS), 3(1), 15-24.

BinObaid, R. (2016). An evaluation of the second intermediate Saudi English language textbook from the teachers' point of view. Advances in Language and Literary Studies, 7(2), 232-248.

Bloom, B. S. (1979). Insan nitelikleri ve okulda ögrenme (Çev. Durmuş Ali Özçelik). Millî Eğitim Basım Evi, Ankara.

Bloom, B. S., Engelhart, M. D., Furst, E. J., Hill, W. H., \& Krathwohl, D. R. (Eds.). (1956). Taxonomy of edu- cational objectives: the classification of educational goals. Handbook 1: cognitive domain. David McKay, New York.

Bosher, S. \& Smalkoski, K. (2002). From needs analysis to curriculum development. designing a course in healthcare communication for immigrant students in the USA. English for Specific Purposes, 21, 59-79.

Çelik, S. (2003). In investigation into students' academic and occupational English language needs at office management and secretarial studies departments of Niğde university's vocational colleges (Master's Thesis). Bilkent University, Ankara.

Chan, V. (2015). Determining students' language needs in a Tertiary setting. Retrieved on 15.06.2018 from https:// americanenglish.state.gov/files/ae/./01-39-3-d.pdf

Changpueng, P., \& Pattanapichet, F. (2015). An analysis of English in the workplace: the needs of engineers in writing in English. Silpakorn University Journal of Social Sciences, Humanities, and Arts, 15(3), 151-176.

Chegeni, N., \& Chegeni, N. (2013). Language curriculum development and importance of needs analysis. ELT Voices -India, 3(4), 2-12.

Chen, I-J., Chang, Y.-H. \& Chang, W.-H. (2016). I learn what I need: needs analysis of English learning in Taiwan. Universal Journal of Educational Research, 4(1), 1-5.

Chostelidou, D. (2010). A needs analysis approach to ESP syllabus design in Greek tertiary education: a descriptive account of students' needs. Procedia Social and Behavioral Sciences 2, 4507-4512.

Chovancov'a, B. (2014). Needs analysis and ESP course design: self-perception of language needs among pre-service students. Studies in Logic, Grammar and Rhetoric, $38(51), 43-57$.

Dehnad, A., Bagherzadeh, R., Bigdeli, S., Hatami, K., \& Hosseini, A. F. (2013). Post graduate ESP curriculum: reading and writing needs. Acta Medica Iranica, 52(5), 406-410

Doruk, S. (2016). A needs analysis study on academic English needs of freshmen students in English medium instructed programs. Yeditepe University Institute of Educational Sciences Department of English Language Teaching, Master of Arts, İstanbul.

Duddley-Evans, T., \& John, M. St. (1998). The difference between present and required knowledge goes back to the gap between present know-how and the exigencies. INTL. Res. J. Appl. Basic. Sci. 4(5), 1014-1020.

Duddley-Evans, T., \& John, M. St. (2009). Development in English for specific purposes: a multidisciplinary approach, Cambridge: CUP.

Eslami, Z. R. (2010). Teachers' voice vs. students' voice: a needs analysis approach to English for academic purposes (EAP) in Iran. English Language Teaching, 3(1), 3-11.

Ferreira, R. R. \& Abbad, G. (2013). Teaching needs assessment: where we are and where we should go. BAR, Rio de Janeiro, 10(1), 77-99.

Gborsong, P. A., Afful, J. B. A., Coker, W., Akoto, O. Y., Twumasi, R., \& Baiden, A. (2015). A needs analysis of undergraduate students of communicative skills: the 
case of tertiary institutions in Ghana. Open Journal of Modern Linguistics, 5, 413-424.

Guiyu, D. \& Yang, L. (2006). An empirical study on business English teaching and development in china-a needs analysis approach. Higher Education Studies, 6(2), 142-153.

Hajana, O. H. O. \& Adam, A. M. A. (2015). The role of needs analysis for the quality of English for specific purposes and English for academic purposes course design. International Journal of Recent Scientific Research, 6(5), 3868-3871.

Harrison, J. J. \& Vanbaelen, R. (2013). Brown's approach to language curricula applied to English communication courses. Shiken Research Bulletin, 17(2), 2-12.

Huh, S. (2006). Task-based needs analysis for a business English course. Second Language Studies, 24(2), 1-64.

Hutchinson, T., \& Waters, A. (1987). English for specific purposes: a learning-centered approach. Cambridge: CUP.

İnceçay, G. \& İnceçay, V. (2010). A case study on needs assessment of English language teachers. Procedia Social and Behavioral Sciences, 2, 317-321.

Jeczelewski, S. (2016). Needs analysis, course design and evaluation of business English. (B.A. Research Project), University of Iceland School of Humanities Department of English. Retrieved on 13.05.2018 from https:// skemman.is/bitstream/1946/24444/1/Needs\%20Analysis $\% 2 \mathrm{C} \% 20$ Course $\% 20$ Design $\% 20$ and $\% 20$ Evaluation\%20of\%20Business\%20English.pdf

Jie, C. (2013). English learner needs analysis: a case study of Beijing institute of petrochemical technology (BIPT). International Journal of Humanities and Social Science, 3(1), 178-182.

Kahraman, O. (2006). A needs analysis to develop an astronomy program for Turkish elementary and secondary schools (MA Thesis). Middle East Technical University, Ankara.

Kar, İ. (2014). İstanbul Sabahattin Zaim Üniversitesi zorunlu yabancı dil hazırlık programı ögrencilerinin Ingilizce dili ihtiyaç analizi. İstanbul Sabahattin Zaim Universitesi Sosyal Bilimler EnstitüsüYabanc1 Diller Eğitimi Ana Bilim Dalı İngiliz Dili Eğitimi Bilim Dalı, Yüksek Lisans Tezi, İstanbul.

Karasar, N. (2013). Bilimsel araştırma yöntemleri. Ankara: Noben Yayınc1lık.

Kaur, S., \& Khan, A. B. M. A. (2010). Language needs analysis of art and design students: considerations for ESP course design. ESP World, 2(9), 1-16.

Kay1, H. (2008). Developing an ESL curriculum based on needs and situation analyses: a case study. Journal of Language and Linguistic Studies, 4(1), 29-49.

Kazar, S. G. \& Mede, E. (2014). Students' and instructors' perceptions of the learning and target needs in an English for specific purposes (ESP) program. K. Ü. Kastamonu Ĕgitim Dergisi, 23(2), 479-498.

Kazar, S. G. \& Mede, E. (2014). The perceptions of ESP students' target needs: a case study. Procedia - Social and Behavioral Sciences, 191, 2526 - 2530.

Kazar, S. G. (2013). Needs analysis study in terms of the perceptions of the students' learning and target needs at an ESP program: a case study (MA Thesis). Yeditepe University, İstanbul.
Khansir, A. A. (2014). Needs analysis and general English language. International Journal of Language Learning and Applied Linguistics World (IJLLALW), 7(2), 161-174.

Kim, H. H. (2013). Needs analysis for English for specific purpose course development for engineering students in Korea. International Journal of Multimedia and Ubiquitous Engineering, 8(6), 279-288.

Kohoutová, İ. (2006). Teaching English to adults: Needs analysis, (Diploma Thesis). Charles University in Prague Faculty of Education Department of English Language and Literature, Prague.

Kösterelioğlu, İ. (2012). Sosyal bilgiler ders programının ögelerinin değerlendirilmesi ve ögretmenlerin hizmet içi eğitim ihtiyaç analizi. Abant İzzet Baysal Üniversitesi, Eğitim Bilimleri Enstitüsü. Doktora Tezi, Bolu.

Külekçi, G. (2009). Assessing the attitudes of pre-service English teachers towards the use of the internet.Ahi Evran Üniversitesi Eğitim Fakültesi Dergisi, 10(3), 153-160.

Kusumoto, Y. (2008). Needs analysis: developing a teacher training program for elementary school homeroom teachers in Japan. Second Language Studies, 26(2), $1-44$.

Li, J. (2014). Needs analysis: an effective way in business English curriculum design. Theory and Practice in Language Studies, 4(9), 1869-1874.

Long, M. H. (2005). Methodological issues in learner needs analysis. second language needs analysis (Ed. Long, M. H). Cambridge University Press Cambridge, New York, Melbourne, Madrid, Cape Town, Singapore, São Paulo, 19-76.

Martins, H. (2017). Revisiting needs analysis: a cornerstone for business English courses. International Journal of English Language \& Translation Studies, 5(1), 57-63.

Mehrdad, A. G. (2012). A subjective needs assessment of EGP students. Procedia - Social and Behavioral Sciences, 31, 546 - 554.

Mohammadi, V. \& Mousavi, N. (2013). Analyzing needs analysis in ESP: A (re)modeling. International Research Journal of Applied and Basic Sciences, 4(5), 1014-1020.

Mohammed Ibrahim, A. S. E. (2017). ESP needs analysis: a case study of PEH students, University of Khartoum. Sino-US English Teaching, 13(12), 905-923.

Morita, M. (2004). Negotiating participation and identity in second language academic communities. TESOL Quarterly, 38(4), 573 - 603.

Moslemi, F. (2011). ESP needs analysis of Iranian ma students: a case study of the University of Isfahan. English Language Teaching, 4(4), 121-129.

Nazim, M. \& Hazarika, Z. (2017). Efficacy of ESP in EFL context: a case study of Saudi Arabia. Arab World English Journal (AWEJ), 8(1), 145-164.

Noom-ura, S. (2013). English-teaching problems in Thailand and Thai teachers' professional development needs. English Language Teaching, 6(11), 139-147.

Otilia, S. M. (2015). Needs analysis in English for specific purposes. Annals of the Constantin Brâncuşi, University of Târgu Jiu, Economy Series, 1(2), 54-55.

Pendidikan, S. (2015). English language communicative 
needs perceived by information and technology professionals: target situation needs analysis (B.A. Research Project).Satya Wacana Christian University, Slatiga.

Pushpanathan, Ln. T. (2013). A need for needs analysis. International Journal of Applied Research \& Studies, 2(1), 1-7.

Rashidi, N. \& Kehtarfard, R. (2014). A needs analysis approach to the evaluation of Iranian third-grade high school English textbook. SAGE, July-September, 1-9.

Rose, P. V. \& Sookraj, R. (2015). Needs analysis: undergraduates' evaluation of a university-wide English language course.Caribbean Educational Research Journal, 3(1), $62-75$.

Rostami, F. \& Zafarghandi, A. M. (2014). EAP needs analysis in Iran: the case of university students in chemistry department. Journal of Language Teaching \& Research, 5(4), 924-934.

Saber, Z. (2014). A needs-based approach to teaching and learning of English for medical sciences purposes. International Journal of Language Learning and Applied Linguistics World (IJLLALW), 5(1), 208-220.

Stern, H. H. (1992). Issues and options in language teaching. Oxford: Oxford University Press.

Stufflebeam, D.L., McCormick, C.H., Brinkerhoff, R.O., \& Nelson, C.O. (1985). Conducting educational needs assessments. eBook ISBN 978-94-011-7807-5.

Tarone, E. \& Yule, G. (1989). Focus on the language learner. Oxford: Oxford University Press.
Tavil, Z M. (2006). A study for the needs analysis of preparatory students at language departments. Education and Science, 31(139), 49-55

Tsao, C. C.H., Wei, A. M.S., \& Fang, A. S.H. (2008). ESP for college students in Taiwan: a survey of student and faculty perceptions. International Symposium on ESP, 245-262.

Tyler, R. W. (1949). Basic principle of curriculum and instruction. Chicago: University of Chicago Press.

Ulum, Ö. G. (2015). Needs analysis study for preparatory class ELT students. European Journal of English Language Teaching, 1(1), 14-28.

Watanabe, Y. (2006). A needs analysis for a Japanese high school EFL general education curriculum. Second Language Studies, 25(1), 83-163.

Wright, P. C. \& Geroy, G. D. (1992). Needs analysis theory and the effectiveness of larg-scale government-sponsored training programs: a case study. Journal of Management Development, 11(5), 16-27.

Yıldırım A. \& Şimşek, H. (2013). Sosyal bilimlerde nitel araştırma yöntemleri. Seçkin, Ankara.

Yutdhana, S. (2004). A needs analysis of Thai high school teachers in using internet applications for teaching English as a foreign language. (MA Thesis). Education Washington State University, Washington.

Zamanian, M. (2014). Relationship between subjective and objective needs analysis of ESP students at M.A. level. International Journal of English and Education, 3(2), 288-312. 


\section{APPENDIX}

Appendix A. Method, data analysis model, and data collection tools in sample studies

\begin{tabular}{|c|c|c|c|}
\hline Researcher, year & Study model & Data analysis method & Data collection tool \\
\hline $\begin{array}{l}\text { Bosher, S. \& } \\
\text { Smalkoski, K. (2002) }\end{array}$ & Experimental & Quantitative and qualitative analyses & Interviews, observation, questionnaire \\
\hline Arık, S. (2002) & Experimental & Quantitative & Questionnaire \\
\hline Çelik, S. (2003) & Survey & Quantitative & Questionnaire \\
\hline Yutdhana, S. (2004) & Survey & Quantitative, SPSS & Questionnaire \\
\hline Morita, M. (2004) & Case study & $\begin{array}{l}\text { Categories and themes emerged } \\
\text { mainly from the collected data, } \\
\text { and preliminary hypotheses about } \\
\text { the settings and participants were } \\
\text { grounded in direct experience at the } \\
\text { research site }\end{array}$ & $\begin{array}{l}\text { Student self-reports, interviews, and } \\
\text { classroom } \\
\text { observations }\end{array}$ \\
\hline Watanabe, Y. (2006) & Survey & $\begin{array}{l}\text { Quantitative and a principal } \\
\text { components analysis }\end{array}$ & Questionnaire \\
\hline Huh, ( 2006) & Mixed-method & Quantitative and qualitative analyses & $\begin{array}{l}\text { Semi-structured interviews and a } \\
\text { questionnaire. }\end{array}$ \\
\hline Kahraman, O. (2006) & Survey & Quantitative, SPSS & Questionnaire \\
\hline Kohoutová, İ. (2006) & Experimental & Quantitative and qualitative analyses & Questionnaires \\
\hline Guiyu, D. \& Yang, L. (2006) & Survey & Target Situation Analysis (TSA) & Questionnaires \\
\hline Tavil, Z M. (2006) & mixed-method & SPSS, percentages, and frequency & Questionnaire and informal interviews \\
\hline Kusumoto, Y. (2008) & Survey & SPSS, percentages, and frequency & $\begin{array}{l}\text { Interviews, observations, and } \\
\text { questionnaires. }\end{array}$ \\
\hline Kayı, H. (2008) & Case study & $\begin{array}{l}\text { percentages and frequency of } \\
\text { responses }\end{array}$ & Questionnaire \\
\hline $\begin{array}{l}\text { Tsao, C. C.H., Wei, A. M.S. } \\
\text { \& Fang, A. S.H. (2008) }\end{array}$ & Survey & Quantitative, SPSS & A self-made questionnaire \\
\hline Külekçi, G. (2009) & Survey & Frequency distribution and SPSS & Questionnaire \\
\hline Eslami, Z. R. (2010) & Survey & Quantitative, SPSS & Questionnaire \\
\hline $\begin{array}{l}\text { İnceçay, G. \& } \\
\text { İnceçay, V. (2010) }\end{array}$ & Case study & Qualitative & Semi-structured interview \\
\hline Chostelidou, D. (2010) & Mixed-method & Quantitative and qualitative analyses & $\begin{array}{l}\text { Questionnaire, semi-structured } \\
\text { interviews }\end{array}$ \\
\hline Kaur and Khan, (2010) & Mixed-method & $\begin{array}{l}\text { quantitative and qualitative analyses, } \\
\text { frequency counts and percentages }\end{array}$ & $\begin{array}{l}\text { Questionnaires for the students and } \\
\text { semi-structured interviews }\end{array}$ \\
\hline Akçadağ, T. (2010) & Survey & SPSS, percentages and frequency & Questionnaire \\
\hline Moslemi, (2011) & Case study & $\begin{array}{l}\text { Quantitative and qualitative analyses, } \\
\text { SPSS }\end{array}$ & Interviews, questionnaires, and texts \\
\hline Mehrdad, A. G. (2012) & Survey & frequency, SPSS & Questionnaire \\
\hline Alfehaid, (2011) & Mixed-method & $\begin{array}{l}\text { Quantitative and qualitative analyses, } \\
\text { SPSS }\end{array}$ & $\begin{array}{l}\text { Questionnaire, semi-structured } \\
\text { interviews, documents and interview } \\
\text { transcriptions }\end{array}$ \\
\hline Baig, M. (2012) & Descriptive & Quantitative & Questionnaires, textbook. \\
\hline Kösterelioğlu, (2012) & Survey & SPSS, percentages and frequency & Questionnaire \\
\hline Aydın, (2014) & Survey & SPSS, percentages and frequency & Questionnaires and interviews \\
\hline Kim, H. H. (2013) & Survey & Quantitative, SPSS & Questionnaire \\
\hline Al- Hamlan, S. A. (2013) & Mixed-method & $\begin{array}{l}\text { Frequency and percentage of } \\
\text { responses }\end{array}$ & Convenient sampling \\
\hline Noom-ura, S. (2013) & Survey & $\begin{array}{l}\text { Descriptive statistics of } \\
\text { frequencies, percentage, } \\
\text { quantitative }\end{array}$ & $\begin{array}{l}\text { Closed-and open-ended } \\
\text { questionnaires }\end{array}$ \\
\hline
\end{tabular}


Appendix A. (Continued)

\begin{tabular}{|c|c|c|c|}
\hline Researcher, year & Study model & Data analysis method & Data collection tool \\
\hline Jie, C. (2013) & Case study & $\begin{array}{l}\text { Target-situation analysis, deficiency } \\
\text { analysis, strategy analysis }\end{array}$ & $\begin{array}{l}\text { The tests of placement, observation } \\
\text { of classes, questionnaires, structured } \\
\text { interviews, and network based } \\
\text { interviews }\end{array}$ \\
\hline $\begin{array}{l}\text { Ayas, Ö. \& } \\
\text { Kırkgöz, Y. (2013) }\end{array}$ & Survey & Quantitative and qualitative, SPSS & Questionnaires and interviews \\
\hline Kazar, 2013 & Case study & Quantitative and qualitative & $\begin{array}{l}\text { Needs analysis questionnaire and a } \\
\text { semi-structured interview }\end{array}$ \\
\hline $\begin{array}{l}\text { Harrison, J. J. \& } \\
\text { Vanbaelen, R. (2013) }\end{array}$ & Experimental & Quantitative and qualitative & Pre-tests and post-tests \\
\hline $\begin{array}{l}\text { Dehnad, A., Bagherzadeh, R., } \\
\text { Bigdeli, S., Hatami, K., \& } \\
\text { Hosseini, A. F. (2013) }\end{array}$ & Mixed-method & Quantitative and qualitative, SPSS & $\begin{array}{l}\text { Ethical and demographic forms, needs } \\
\text { analysis questionnaires, and a form of } \\
\text { semi-structured interview }\end{array}$ \\
\hline Khansir, A. A. (2014) & Survey & Quantitative, SPSS & $\begin{array}{l}\text { Background questionnaire; teachers' } \\
\text { questionnaire }\end{array}$ \\
\hline Kazar and Mede, (2014) & Mixed-method & Quantitative and qualitative, SPSS & $\begin{array}{l}\text { The questionnaire, a semi-structured } \\
\text { interview }\end{array}$ \\
\hline Saber, Z. (2014) & Survey & Quantitative and qualitative, SPSS & Semi-structured and the questionnaire. \\
\hline Zamanian, M. (2014) & Survey & Quantitative, SPSS & $\begin{array}{l}\text { The students' and instructors' } \\
\text { questionnaires }\end{array}$ \\
\hline Angus, K. B. (2014) & Survey & Quantitative and qualitative & syllabi, questionnaires, and interviews \\
\hline Kar, İ. (2014) & Descriptive & Frequency and percentage of responses & Questionnaire \\
\hline $\begin{array}{l}\text { Rashidi, N. \& } \\
\text { Kehtarfard, R. (2014) }\end{array}$ & Survey & Quantitative, SPSS & Questionnaires \\
\hline $\begin{array}{l}\text { Rostami, F. \& } \\
\text { Zafarghandi, A. M. (2014) }\end{array}$ & Case study & Quantitative, SPSS & Questionnaires \\
\hline Chovancov×a, B. (2014) & Survey & The actual target situations & Questionnaire survey \\
\hline Al-Hamlan, S. A. (2015) & $\begin{array}{l}\text { A descriptive } \\
\text { analytical approach }\end{array}$ & $\begin{array}{l}\text { Quantitative and qualitative analyses, } \\
\text { SPSS }\end{array}$ & $\begin{array}{l}\text { The questionnaire, a semi-structured } \\
\text { interview }\end{array}$ \\
\hline $\begin{array}{l}\text { Changpueng, P. \& } \\
\text { Pattanapichet, F. (2015) }\end{array}$ & Mixed-method & $\begin{array}{l}\text { Quantitative and qualitative analyses, } \\
\text { SPSS }\end{array}$ & Questionnaire and interview \\
\hline Ulum, Ö. G. (2015) & Descriptive & $\begin{array}{l}\text { Quantitative and qualitative analyses, } \\
\text { SPSS }\end{array}$ & $\begin{array}{l}\text { Questionnaire with open-ended } \\
\text { questions }\end{array}$ \\
\hline Chan, V. (2015) & Survey & Quantitative & Questionnaires \\
\hline Pendidikan, S. (2015) & Experimental & Target situation analysis & Questionnaires \\
\hline $\begin{array}{l}\text { Gborsong, P. A., Afful, J. } \\
\text { B. A., Coker, W., Akoto, } \\
\text { O. Y., Twumasi, R., \& } \\
\text { Baiden, A. (2015) }\end{array}$ & $\begin{array}{l}\text { Descriptive } \\
\text { survey }\end{array}$ & $\begin{array}{l}\text { Quantitative and qualitative } \\
\text { paradigms }\end{array}$ & $\begin{array}{l}\text { Reading proficiency } \\
\text { test (pre- and post-test design) } \\
\text { Interviews with staff and } \\
\text { Students }\end{array}$ \\
\hline $\begin{array}{l}\text { Rose, P. V. \& Sookraj, } \\
\text { R. (2015) }\end{array}$ & Descriptive & Quantitative, SPSS & Questionnaires \\
\hline $\begin{array}{l}\text { Hajana, O. H. O. \& } \\
\text { Adam, A. M. A. (2015) }\end{array}$ & Mixed-method & Frequencies, percentage & Questionnaire \\
\hline BinObaid, R. (2016) & Survey & SPSS quantitative & Questionnaire \\
\hline Alebachew, S. (2016) & Mixed-method & $\begin{array}{l}\text { Observation and document analysis, } \\
\text { SPSS }\end{array}$ & $\begin{array}{l}\text { Questionnaire, observation and } \\
\text { document }\end{array}$ \\
\hline $\begin{array}{l}\text { Chen, I-J., Chang, Y.-H. \& } \\
\text { Chang, W.-H. (2016) }\end{array}$ & Survey & Quantitative & Questionnaire with Likert's 5 scales \\
\hline Doruk, S. (2016) & Descriptive & Quantitative and qualitative, SPSS & Questionnaire and interview \\
\hline $\begin{array}{l}\text { Nazim, M. \& } \\
\text { Hazarika, Z. (2017) }\end{array}$ & Case study & Quantitative and qualitative & $\begin{array}{l}\text { Likert's } 5 \text { scales, semi-structured } \\
\text { interviews }\end{array}$ \\
\hline $\begin{array}{l}\text { Mohammed Ibrahim, A. S. } \\
\text { E. (2017) }\end{array}$ & Survey & Quantitative and qualitative & Questionnaire and interview \\
\hline
\end{tabular}

